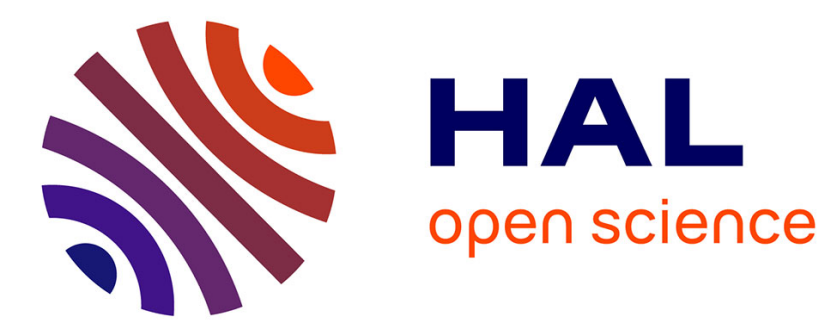

\title{
Input of molecular analysis in medical management of primary brain tumor patients
}

Ahmed Idbaih, Alberto Duran-Peña, Charlotte Bonnet, François Ducray

\section{To cite this version:}

Ahmed Idbaih, Alberto Duran-Peña, Charlotte Bonnet, François Ducray. Input of molecular analysis in medical management of primary brain tumor patients. Revue Neurologique, 2015, 171 (6-7), pp.457-465. 10.1016/j.neurol.2015.04.002 . hal-01158523

\section{HAL Id: hal-01158523 \\ https://hal.sorbonne-universite.fr/hal-01158523}

Submitted on 1 Jun 2015

HAL is a multi-disciplinary open access archive for the deposit and dissemination of scientific research documents, whether they are published or not. The documents may come from teaching and research institutions in France or abroad, or from public or private research centers.
L'archive ouverte pluridisciplinaire HAL, est destinée au dépôt et à la diffusion de documents scientifiques de niveau recherche, publiés ou non, émanant des établissements d'enseignement et de recherche français ou étrangers, des laboratoires publics ou privés. 


\section{Input of molecular analysis in medical management of primary brain tumor patients}

Apport des données moléculaires dans la prise en charge médicale des patients souffrant de tumeur cérébrale primitive

\section{Auteurs}

Ahmed Idbaih ${ }^{1,2,3,4,5}$, Alberto Duran-Peña ${ }^{1,2,3,4,5}$, Charlotte Bonnet ${ }^{6,7}$, François Ducray ${ }^{6,7}$

1 AP-HP, Groupe Hospitalier Pitié-Salpêtrière, Service de neurologie 2-Mazarin, Paris, France.

2 Sorbonne Universités, UPMC Univ Paris 06, UM 75, ICM, F-75013 Paris, France

3 Inserm, U 1127, ICM, Paris, F-75013 Paris, France

4 CNRS, UMR 7225, ICM, Paris, F-75013 Paris, France

5 ICM, Paris, 75013 France

6 Service de Neuro-oncologie, Hôpital Neurologique, Hospices Civils de Lyon

7 Université Claude Bernard Lyon 1

\section{Corresponding Author:}

Ahmed Idbaih. Service de Neurologie 2-Mazarin, Groupe Hospitalier Pitié-Salpêtrière. 47-83, Boulevard de l'Hôpital, 75013 Paris, France. Tel: 33-1-42-16-03-85. Fax: 33-1-42-16-04-18. Email: ahmed.idbaih@gmail.com or ahmed.idbaih@psl.aphp.fr 


\section{Abstract}

Primary brain tumors is a large group of malignant and non-malignant tumors including heterogeneous entities with various biological and clinical behaviors. Up to recently diagnosis of brain cancers, that drives treatment decision-making, was based on integration of clinical, radiological and pathological features of patients and tumors. Over last years, practical neurooncology has entered an era of molecular-based personalized medicine. Indeed, molecular features of tumors provide critical information to physicians for daily clinical management of patients and for design of relevant clinical research.

Sporadic gliomas or glial tumors are the most common primary brain tumors in adults. Recently, their medical management has been revolutionized by molecular data. Indeed, optimal therapeutic management of grade III glioma patients requires now assessment of chromosome arms $1 \mathrm{p} / 19 \mathrm{q}$ copy number and $I D H$ mutational statuses as predictive and prognostic biomarkers. Indeed, two large phase III clinical trials have demonstrated that early chemotherapy plus radiotherapy, versus radiotherapy alone, doubles median overall survival of patients suffering from $1 \mathrm{p} / 19 \mathrm{q}$ co-deleted and/or $I D H$ mutated anaplastic oligodendroglial tumor. Interestingly, both biomarkers have been identified in a large proportion of WHO grade II gliomas, their clinical value, in this population, is under investigations through multiple phase III clinical trials. In sporadic WHO grade I gliomas and specifically in pilocytic astrocytomas, MAPK signaling pathway activation is a frequent event, mainly due to genetic alterations involving $B R A F$ gene. This characteristic opens new therapeutic perspectives using MAPK signaling pathway inhibitors. Finally, in the most aggressive gliomas, WHO grade IV gliomas, two critical biomarkers have been identified: (i) $M G M T$ promoter methylation associated with longer survival and better response to chemotherapy 
and (ii) $I D H$ mutations predicting better prognosis. Although, further studies are needed, $M G M T$ promoter methylation will undoubtedly be transferred soon in clinical practice.

Molecular characteristics start to be valuable and indispensable in neuro-oncology for a better management of brain tumors patients. The upcoming future will be marked by identification of novel molecular biomarkers and their validation for clinical practice.

\section{Keywords}

brain tumor; glioma; treatment; biomarker 


\section{Résumé}

Jusqu'à tout récemment, le diagnostic des tumeurs cérébrales, pivot de la prise en charge thérapeutique, était basé sur les caractéristiques clinico-radiologiques et neuropathologiques du patient et de la tumeur.

Ces dernières années, la neuro-oncologie clinique est entrée dans l'ère de la médecine personnalisée moléculaire. En effet, les caractéristiques moléculaires de la tumeur apportent des informations majeures au clinicien pour le traitement du patient.

Les gliomes sont les tumeurs cérébrales primitives les plus fréquentes chez l'adulte. Leur prise en charge médicale a été transformée, depuis peu, par les données moléculaires. A titre d'exemple, le traitement optimal des patients souffrant d'un gliome de grade III nécessite désormais la détermination des statuts des chromosomes 1p et 19q et des gènes IDH. En effet, deux essais cliniques de phase III ont démontré que la chimiothérapie précoce plus la radiothérapie, versus la radiothérapie seule, double la survie globale médiane des patients souffrant d'un gliome grade III 1p/19q co-délété et/ou IDH muté.

Les données moléculaires sont dorénavant indispensables en neuro-oncologie pour une prise en charge médicale optimale des patients. Les prochaines années seront incontestablement marquées, dans tous les sous-types de tumeurs cérébrales, par l'identification et la validation de nouveaux biomarqueurs moléculaires pertinents pour la pratique clinique.

\section{Mots clés}

Tumeur cérébrale; gliome; traitement; biomarqueur 


\section{Introduction}

Diagnosis of primary brain tumors in adults is based on cytological and pathological features (i.e. morphological aspects of tumor cells and their tissue organization). This subgroup of tumors is very heterogeneous in terms of pathology but also in terms of prognosis and response to anti-tumor treatments. Indeed, the World Health organization (W.H.O.) individualizes more than 100 entities defined by their putative embryological cell of origin, their anatomical location and their grade of malignancy from I to IV[1]. Taking into account all these parameters, five mains groups of primary brain tumors are individualized: (i) neuroepithelial tumors, (ii) meningeal tumors, (iii) hematopoietic tumors, (iv) germ cell tumors and (v) hypothalamopituitary tumors.

These main subgroups are also subdivided into multiple subcategories. In the present review illustrating the impact of molecular characteristics of brain tumors in medical management of neuro-oncology patients, we will focus on the largest subgroup of neuroepithelial tumors in adults (i.e. glial tumors or gliomas).

Indeed, gliomas are the most common primary brain tumors in adults. Every year, approximately 3000 to 4000 new cases are diagnosed in France[2]. Based on tumor cell phenotype and grade of malignancy integrating cell density, cell differentiation, mitosis, necrosis and angiogenesis eight main subgroups of gliomas are distinguished by the W.H.O. classification: (i) grade I astrocytomas, (ii) grade II astrocytomas, (iii) grade II oligoastrocytomas, (iv) grade II oligodendrogliomas, (v) grade III astrocytomas (vi) grade III oligoastrocytomas, (vii) grade III oligodendrogliomas, and (viii) grade IV astrocytomas or glioblastomas[1]. 
Although the morphological aspect is quite similar within each glioma subgroup, clinical behavior of tumors within the same pathological group is very heterogeneous disconcerting physicians and limiting their ability to predict accurately clinical course, with or without treatments, in individual patient[3]. Therefore additional biomarkers are needed in clinics for better anticipation of clinical course of the disease.

Over the last years, mainly due to the development of novel high throughput technologies in molecular biology, significant advances have been accomplished in molecular characterization of brain tumors paving the way for a personalized medical management of glioma patients combining clinical, pathological, radiological and molecular features of tumors and patients. Through the group of gliomas, we will illustrate how molecular data already help physicians to overcome intertumor clinical heterogeneity, to guide treatments decision-making and to design relevant clinical research. 


\section{Grade IV glioma or glioblastoma}

Glioblastoma or grade IV glioma is the most common and the most aggressive primary malignant brain tumors in adults. The annual incidence rate is estimated around 3.19 per 100000. Glioblastoma occur mainly in adults aged between 60 to 70 years old[4,5].

This tumor type is characterized by poorly differentiated tumor cells, abundant angiogenesis, high mitotic activity, areas of necrosis, and high tumor cells density. Several morphologic variant have been identified with imperfectly known clinical and biological significance[6].

The radiological aspect is quite characteristic. On MRI, glioblastoma usually appears as a large contrast ring-enhancing mass, with surrounding edema, central necrosis and mass effect on normal brain structures.

The main clinical prognostic factors are age and performance status. Indeed, younger patients (i.e. below 70 years old although additional threshold were used) and patients with good performance status (i.e. Karnofsky performance score above 70 although additional threshold are used) have better survival independently of treatments[7].

The standard of care for glioblastoma patients in good clinical conditions relies on maximal safe surgical resection, radiotherapy with concurrent temozolomide (an alkylating cytotoxic chemotherapeutic agent) and adjuvant temozolomide in young patients while it relies on hypofractioned radiotherapy alone in elderly patients $[8,9]$.

Comprehensive molecular analysis of glioblastoma have been performed over the last years, worldwide, allowing identification of multiple molecular abnormalities with biological and clinical relevance.

$M G M T$ is a gene located on chromosome 10 that encodes Methylguanine DNA methylguanine DNA methyltransferase, a DNA repair enzyme. MGMT protein, when expressed, removes alkylating lesions induced by alkylating chemotherapeutic agents to 
DNA. It has been shown in a translational study linked to a phase III clinical trial that $M G M T$ promoter methylation is a prognostic biomarker but also a predictive biomarker of response to the standard of care for glioblastoma (i.e. radiotherapy with concurrent temozolomide plus adjuvant temozolomide). Indeed, patients with MGMT-methylated-glioblastoma survive longer (median overall survival, median $\mathrm{OS}=18.2$ months) compared to their $M G M T$ unmethylated counterparts (median OS=12.2 months) regardless of the treatments received. Similarly, when treated with combined treatment, patients with $M G M T$-methylated tumor survive longer (median $\mathrm{OS}=21.7$ months) compared to patients with $M G M T$-unmethylated tumor (median OS=12.7 months)[10]. The technical approach to assess $M G M T$ promoter status in individual case is still debated making this major biomarker not enough mature for clinical use[11,12]. The upcoming years will permit to validate and standardize its use in clinics.

EGFRvIII, is a truncated variant of EGFR (Epidermal growth factor receptor) located on chromosome 7. EGFRvIII induces a constitutive activation, independently from the ligand, of EGFR and EGFR signaling pathway. Interestingly, this genetic alteration is rare in normal cells and other subtypes cancer cell types. Therefore, EGFRvIII detected in approximately $20 \%$ of newly diagnosed glioblastoma appears as an interesting target for vaccine strategies[13]. A phase III clinical trial testing an EGFRvIII vaccine (rindopepimut) is ongoing after promising data resulting from a phase II clinical trial[14].

Additional molecular alterations have been identified in glioblastoma[15-18]. Although some of them are widely used as inclusion or stratification criteria in clinical trials, they have not reached clinical use yet.

\section{WHO grade III gliomas or anaplastic gliomas}


WHO grade III gliomas or anaplastic gliomas, include anaplastic astrocytomas, anaplastic oligoastrocytomas and anaplastic oligoastrocytoma. Anaplastic glioma are relatively rare gliomas accounting for approximately $20-25 \%$ of all gliomas. The median age of occurrence is 50 years[19]. Pathological examination of anaplastic gliomas reveals signs of malignancy (i.e. cytonuclear atypia and/or mitotic activity)[1]. The radiological aspect on MRI is extremely heterogeneous ranging from a diffuse-low grade-like tumor (i.e. non contrastenhanced) to a glioblastoma-like lesion (i.e. ring contrast-enhancement with hypointense central area).

Similarly to imaging features, prognosis of anaplastic gliomas patients is also very heterogeneous across patients. Indeed, $25 \%$ of patients are short survivors (below 24 months) and $25 \%$ long survivors (over 10 years)[20,21]. The management of these tumors relies on maximal safe resection, radiotherapy and/or chemotherapy.

Significant advances have been accomplished in molecular characterization of anaplastic gliomas over the last twenty years allowing deciphering this heterogeneous subgroup of diffuse gliomas into more homogeneous histomolecular subgroups[22,23]. Indeed, three molecular subgroups with strong clinical relevance have been identified: (i) chromosome arms $1 \mathrm{p} / 19 \mathrm{q}$ co-deleted and $I D H$ mutated tumor, (ii) Non $1 \mathrm{p} / 19 \mathrm{q}$ co-deleted and $I D H$ mutated and (iii) Non 1p/19q co-deleted and Non IDH mutated[24,25].

The whole chromosome arms $1 \mathrm{p}$ and $19 \mathrm{q}$ co-deletion mediates an unbalanced reciprocal translocation $\mathrm{t}(1 ; 19)(\mathrm{q} 10 ; \mathrm{p} 10)[26-28]$ (Figure 1). The putative chimeric gene resulting from this translation has not been identified so far[29]. However, frequent inactivating point mutations have been identified in FUBPl (far upstream element -FUSE- binding protein 1) gene and in CIC (capicua transcriptional repressor) gene located on chromosome arm 1p and $19 q$ respectively[30]. CIC is a transcriptional regulator of tyrosine kinase receptors signaling 
pathway while FUBP1 transcriptional regulator of $M Y C$ (v-myc avian myelocytomatosis viral oncogene homolog) gene[31,32].

$I D H$ (isocitrate dehydrogenase 1, NADP+) gene family encompasses three isoforms $I D H 1$, IDH2 and IDH3. IDH3 has not been shown to be involved in gliomas. In contrast, the cytosolic isoforms IDHI (encoded from chromosome arm 2q) and the mitochondrial isoform IDH2 (encoded from chromosome 15q) have been shown to be mutated in $\sim 50 \%$ of anaplastic gliomas. Both genes are involved in cell metabolism. While the wild-type IDH enzyme convert isocitrate to 2 hydroxyglutarate, the mutated variant converts isocitrate to alphaketoglutarate acting as an oncometabolite promoting oncogenesis.

Molecular characterization is now mandatory for an optimal medical management of WHO grade III glioma patients. Two large phase III randomized controlled phase III clinical trials conducted by the EORTC (European Organisation for Research and Treatment of Cancer) and the RTOG (Radiation Therapy Oncology Group) have demonstrated that patients suffering from anaplastic oligodendroglial tumor exhibiting chromosome arms $1 \mathrm{p}$ and 19q co-deletion double their median OS if they received early (i.e. just before or just after radiotherapy) cytotoxic chemotherapy with PCV regimen versus radiotherapy alone ( $~ 8$ years versus $\sim 16$ years). PCV regimen includes the following cytotoxic agents: (i) procarbazine, (ii) lomustine and, (iii) vincristine $[21,20]$.

Similarly, based on the RTOG phase III clinical trial, patients exhibiting IDH mutated anaplastic glioma benefit from early PCV (5.5 years versus 3.3 years) [33] (Figure 2). Overall 1p/19q co-deleted and $I D H$ mutated anaplastic gliomas have the best and the intermediate prognosis respectively while non $1 \mathrm{p} / 19 \mathrm{q}$ co-deleted and non $I D H$ mutated anaplastic gliomas have the worse prognosis. 
The group of anaplastic gliomas clearly demonstrated that molecular features of tumors have nowadays dramatic therapeutic impacts in medical management of primary brain tumor patients.

\section{WHO grade II glioma or diffuse low grade gliomas}

WHO grade II gliomas or diffuse low grade gliomas include grade II astrocytomas, grade II oligoastrocytomas and grade II oligodendrogliomas. They represent approximately $15-20 \%$ of all diffuse gliomas. They affect young adults with median age at diagnosis of $~ 40$ years[19]. On imaging (i.e. brain MRI), diffuse low grade gliomas appear classically as T1 hypointense without contrast enhancement and T2 hyperintense lesions.

WHO grade II gliomas are infiltrative lesions with low level proliferative activity [1]. Indeed, WHO grade II gliomas are slow growing primary malignant brain tumors. However, they virtually all recur with volumetric or anaplastic (i.e. higher grade of malignancy) tumor progression compromising prognosis and quality of life of patients.

Prognosis of diffuse low grade gliomas is heterogeneous varying from a couple of years to more than 20 years. The median OS is 15 years[34]. The clinical prognostic factors are: (i) age, (ii) astrocytoma phenotype, (iii) tumor size, (iv) crossing the blood brain barrier, (v) neurological deficit at diagnosis, (vi) cognitive status, (v) extend of surgery and (vi) growth velocity[35-38].

Treatment of WHO grade II gliomas relies on maximal safe surgery for resectable tumor. For unresectable patients, after diagnostic biopsy, two therapeutic strategies are recommended based on the prognostic risk-group, the tumor growth rate and the seizure. The following parameters are included the risk classification: (i) age >40 years, (ii) astrocytoma phenotype, (iii) tumor size $>6 \mathrm{~cm}$, (iv) crossing midline and, (v) neurologic deficit. Patients with a score 
$>=3$ are classified as high-risk patients for whom medical treatment is recommended. Patient exhibiting low-risk tumor can be managed with close clinical and radiological monitoring (i.e. wait and see strategy). Although debated due late-onset radiation-induced cognitive troubles, radiotherapy remains the standard of care in diffuse low-grade glioma patients requiring medical treatment. However, upfront chemotherapy merits consideration and discussion in particular cases[39,40].

Similarly to what was described above in anaplastic gliomas, molecular characterization of WHO grade II gliomas has identified three major molecular subgroups with clinical relevance: (i) $1 \mathrm{p} / 19 \mathrm{q}$ co-deleted and $I D H$ mutated tumor, (ii) Non $1 \mathrm{p} / 19 \mathrm{q}$ co-deleted and $I D H$ mutated and (iii) Non 1p/19q co-deleted and non $I D H$ mutated. Although, several studies have shown the positive prognostic value of $1 \mathrm{p} / 19 \mathrm{q}$ co-deletion and $I D H$ mutation in WHO grade II diffuse gliomas, three major clinical trials are currently investigating prospectively in a robust manner their prognostic and predictive value (www.clinicaltrials.gov).

Molecular biomarkers will undoubtedly be integrated in medical management of diffuse low grade gliomas soon based on the results of the ongoing phase III clinical trials.

\section{Grade I glioma}

The vast majority of WHO grade I gliomas are pilocytic astrocytomas. These WHO grade I are the most common glioma in children. Pilocytic astrocytomas in adults are rare and occur mainly in young adults at $20-25$ years. The annual incidence rate of grade $\mathrm{I}$ in adults is estimated less than $0.33 / 100000[4,5,41]$.

The radiological features of pilocytic astrocytomas are singular with contrast enhanced nodule hooked on the wall of a cystic cavity. In adults, pilocytic astrocytomas are located in the supratentorial areas and infratentorial regions in $40 \%$ of cases in $40 \%$ respectively[41]. 
Under the microscope, pilocytic astrocytomas are characterized by: (i) Rosenthal fibers, corkscrew-shaped intracytoplasmic inclusions (ii) eosinophilic granular bodies, (iii) cluster of tumor cells, (iv) bipolar diploid cell and (v) calcifications[42].

This entity is peculiar in the large subgroup of gliomas. Indeed, it is the sole glioma that is curable with a complete tumor surgical resection. The malignant transformation, in contrast to the other subtype of gliomas (i.e. diffuse glioma) remains exceptional and debated.

Treatment of pilocytic astrocytoma relies on complete safe surgical resection. Radiotherapy and cytotoxic chemotherapy are usually used faced to a progressive unresectable disease.

Oncogenesis of grade I gliomas is mainly driven by Neurofibromin 1 (NF1) - Rat sarcoma viral oncogene homolog (RAS)-RAF-Mitogen-Activated Protein Kinase (MAPK) signaling pathway. Activation of MAPK intracellular signaling pathway induces tumor cells proliferation. Several genetic alterations activating MAPK signaling pathway have been identified in pilocytic astrocytoma. The most common genetic alteration is duplicationrearrangement of $B R A F(\mathrm{~V}$-raf murine sarcoma viral oncogene homolog B1) gene located on chromosome 7q34. BRAF encodes an intracellular serine-threonine kinase which is tandemduplicated and fused with various partners. The most frequent partner is KIAA-1549 also located in chromosome $7 \mathrm{q} 34$. The fusion $B R A F-K I A A 1549$ is observed in approximately two third of pilocytic astrocytomas. Although less frequent, additional genetic alterations disrupting MAPK signaling pathway have been reported in pilocytic astrocytomas[43,44].

The prognostic value of BRAF-fusion remains unsettled with conflicting results in the literature[44].

Multiple MAPK pathway inhibitors (i.e. BRAF inhibitor, MEK inhibitor) are already available or under development. Pilocytic astrocytomas exhibiting genetic abnormalities disrupting MAPK are candidate diseases for these molecular targeted therapies. Interestingly, it has been shown that pilomyxoid astrocytoma, ganglioglioma and pleomorphic 
xanthoastrocytoma, which are other subtypes of gliomas with frequent MAPK signaling pathway activation, can respond to vemurafenib[45-47].

\section{Discussion}

In parallel to their impact in our understanding of basic central nervous system oncogenesis, genetic and more broadly molecular characteristics of brain tumors have increasing importance in medical management of neuro-oncology patients. Indeed, these molecular alterations become more and more essential in the standard of care of patients suffering from brain cancers. These molecular alterations are used as biomarkers or molecular targets for developing innovative molecular drugs and/or for designing smart clinical trials.

Although the vast majority of primary malignant brain tumors are sporadic, constitutional single nucleotid polymorphism associated with increased susceptibility have been identified. These polymorphisms as biomarkers of susceptibility to develop glioma participate to our understanding of gliomagenesis[48,49].

Diagnosis of brain tumors and particularly in WHO grade I//II gliomas is challenging in practice with high interobserver and intraobserver variability. Indeed, the semi-quantitative pathological and histological criteria of the WHO classification lack of reproducibility and clear-cut threshold. Molecular biomarkers already help pathologists in diagnosis. For instance, IDH immunostaining detecting the most common IDH1 mutation R132H strongly argue in favor of a grade II or grade III glioma[50].

Prognosis is frequently discussed between in one hand neuro-oncologist and in the other hand glioblastoma patient and his family. In diffuse WHO IV tumor, MGMT promoter methylation status can be very helpful helping the physician to soften the dismal prognostic associated 
with this aggressive disease. Nonetheless, prognostic prediction should be cautious in individual patient due to interaction with other prognostic factors[51].

Treatment decision-making is pivotal in WHO grade III tumors. Radiotherapy was the standard of care for several years. PCV-chemotherapeutic regimen was known to be efficient in anaplastic gliomas and was deferred at recurrence. As mentioned above, two phase III clinical trials have demonstrated that delivering early PCV at diagnosis doubles median overall survival of patients suffering from $1 \mathrm{p} / 19 \mathrm{q}$ co-deleted anaplastic glioma. This results has dramatically changed treatment decision-making and illustrates that molecular features are now mandatory for an optimal management of anaplastic glioma patients. IDH status is also mandatory for management of WHO grade III glioma patients. Additional biomarkers will undoubtedly be incorporated in neuro-oncology algorithms within the next years (e.g. MGMT promoter methylation; ATRX mutation, Histone H3.3 mutation; TERT promoter mutation) in routine neuro-oncology [16,52-54]. ATRX mutations and TERT promoter mutations are mutually exclusive mutations which both result in the maintenance of telomere length. ATRX mutations are observed in most $I D H$-mutated gliomas without $1 \mathrm{p} / 19 \mathrm{q}$ codeletion. They are easy to identify (nuclear loss of expression) and mutually exclusive with the $1 \mathrm{p} / 19 \mathrm{q}$ co-deletion. TERT promoter mutations are frequently found either in de novo glioblastomas $(80 \%)$ or in $1 \mathrm{p} / 19 \mathrm{q}$ co-deleted gliomas (nearly constant). In de novo glioblastomas they are associated with poor prognosis. Histone H3.3 mutations are frequently found in brainstem gliomas, especially in children and young adults, where they represent an interesting diagnostic biomarker.

Finally, molecular characterization of brain tumors has identified targets for innovative treatment. Indeed, some molecular alteration are already actionable using molecular targeted drugs. For instance, MET amplification detected in some glioblastoma are druggable using crizotinib a c-MET inhibitor[55]. 
In summary, these last years have inaugurated the entry in the molecular neuro-oncology era (Table). Indeed, nowadays, neuro-oncology practice should integrate clinical, radiological, pathological and molecular features of patients and their tumor. Although molecular data have opened diagnostic and therapeutic avenues they also raised several challenges that need to be addressed other the next years: (i) defining and validating the role of each biomarker in clinical management of brain tumor patients, (ii) defining and validating the technics to determinate each biomarker. 


\section{Legend to figures}

Figure 1. Single nucleotid polymorphism (SNP) array profiles of two anaplastic oligodendrogliomas.

Legend. For each chromosome, the telomere of the short arm is on the left and the telomere of the long arm is on the right. The y-axis corresponds to the B allele frequency (BAF). For each SNP two intensities are measured corresponding to alleles A and B. The BAF corresponds to the $\mathrm{B} /(\mathrm{A}+\mathrm{B})$ ratio. If only the $\mathrm{B}$ allele is present then the ratio is $1(\mathrm{~B} / \mathrm{B})$, if both alleles are present then the ratio is $0.5(\mathrm{~B} / \mathrm{A}+\mathrm{B})$, if only the $\mathrm{A}$ allele is present then the ratio is $0(0 / \mathrm{B})$. If there is a loss of heterozygosity due to chromosome loss, then the value of the BAF is either 0 or 1. If there is a gain then the ratio is either $0.3(\mathrm{~B} / \mathrm{A}+\mathrm{A}+\mathrm{B})$ or $0.6(\mathrm{~B}+\mathrm{B} / \mathrm{A}+\mathrm{B}+\mathrm{B})$. On the top, a classic 1p/19q co-deletion with a complete loss of $1 \mathrm{p}$ and $19 \mathrm{q}$. On the bottom, a « false $» 1 \mathrm{p} / 19 \mathrm{q}$ co-deletion with a partial, yet proximal, deletion of the chromosome arm $1 \mathrm{p}$ and a complete deletion of chromosome 19 with concurrent losses on chromosomes $6,8,11,12,16$ and 18 and gains on chromosomes 1q, 11, 12 and 17.

Figure 2. Current approach to anaplastic gliomas as recommended by the French POLA (Prise en charge des tumeurs oligodendrogliales anaplasiques) network

Legend. RT, radiotherapy; PCV, procarbazine, lomustine and vincristine chemotherapeutic regimen; IDH, isocitrate dehydrogenase; CATNON trial, NCT00626990; TMZ, temozolomide. 


\section{Acknowledgements}

The genomic profiles are part of the national program Cartes d'Identité des Tumeurs ${ }^{\circledR}$ (CIT) http://cit.ligue-cancer.net/ funded and developed by the Ligue Nationale contre le cancer. We acknowledge the program "Investissements d'avenir" ANR-10-IAIHU-06. Institut Universitaire de Cancérologie (IUC).

\section{Conflits of interet}

The authors declare that they have no conflicts of interest concerning this article 


\section{References}

[1] Louis DN, Ohgaki H, Wiestler OD, Cavenee WK, Burger PC, Jouvet A, et al. The 2007 WHO classification of tumours of the central nervous system. Acta Neuropathol (Berl) 2007;114:97-109. doi:10.1007/s00401-007-0243-4.

[2] Rigau V, Zouaoui S, Mathieu-Daudé H, Darlix A, Maran A, Trétarre B, et al. French brain tumor database: 5-year histological results on 25756 cases. Brain Pathol Zurich Switz 2011;21:633-44. doi:10.1111/j.1750-3639.2011.00491.x.

[3] Van den Bent MJ. Interobserver variation of the histopathological diagnosis in clinical trials on glioma: a clinician's perspective. Acta Neuropathol (Berl) 2010;120:297-304. doi:10.1007/s00401-010-0725-7.

[4] Ostrom QT, Gittleman H, Liao P, Rouse C, Chen Y, Dowling J, et al. CBTRUS statistical report: primary brain and central nervous system tumors diagnosed in the United States in 2007-2011. Neuro-Oncol 2014;16 Suppl 4:iv1-63. doi:10.1093/neuonc/nou223.

[5] Ostrom QT, Bauchet L, Davis FG, Deltour I, Fisher JL, Langer CE, et al. The epidemiology of glioma in adults: a "state of the science" review. Neuro-Oncol 2014;16:896-913. doi:10.1093/neuonc/nou087.

[6] Karsy M, Gelbman M, Shah P, Balumbu O, Moy F, Arslan E. Established and emerging variants of glioblastoma multiforme: review of morphological and molecular features. Folia Neuropathol Assoc Pol Neuropathol Med Res Cent Pol Acad Sci 2012;50:301-21.

[7] Li J, Wang M, Won M, Shaw EG, Coughlin C, Curran WJ, et al. Validation and simplification of the Radiation Therapy Oncology Group recursive partitioning analysis classification for glioblastoma. Int J Radiat Oncol Biol Phys 2011;81:623-30. doi:10.1016/j.ijrobp.2010.06.012. 
[8] Stupp R, Mason WP, van den Bent MJ, Weller M, Fisher B, Taphoorn MJB, et al. Radiotherapy plus concomitant and adjuvant temozolomide for glioblastoma. N Engl J Med 2005;352:987-96. doi:10.1056/NEJMoa043330.

[9] Keime-Guibert F, Chinot O, Taillandier L, Cartalat-Carel S, Frenay M, Kantor G, et al. Radiotherapy for glioblastoma in the elderly. N Engl J Med 2007;356:1527-35. doi:10.1056/NEJMoa065901.

[10] Hegi ME, Diserens A-C, Gorlia T, Hamou M-F, de Tribolet N, Weller M, et al. MGMT gene silencing and benefit from temozolomide in glioblastoma. $\mathrm{N}$ Engl $\mathrm{J}$ Med 2005;352:997-1003. doi:10.1056/NEJMoa043331.

[11] Wick W, Weller M, van den Bent M, Sanson M, Weiler M, von Deimling A, et al. MGMT testing--the challenges for biomarker-based glioma treatment. Nat Rev Neurol 2014;10:372-85. doi:10.1038/nrneurol.2014.100.

[12] Tabouret E, Chinot O, Sanson M, Loundou A, Hoang-Xuan K, Delattre J-Y, et al. Predictive biomarkers investigated in glioblastoma. Expert Rev Mol Diagn 2014;14:883-93. doi:10.1586/14737159.2014.945436.

[13] Gan HK, Cvrljevic AN, Johns TG. The epidermal growth factor receptor variant III (EGFRvIII): where wild things are altered. FEBS J 2013;280:5350-70. doi:10.1111/febs.12393.

[14] Sampson JH, Heimberger AB, Archer GE, Aldape KD, Friedman AH, Friedman HS, et al. Immunologic escape after prolonged progression-free survival with epidermal growth factor receptor variant III peptide vaccination in patients with newly diagnosed glioblastoma. J Clin Oncol Off J Am Soc Clin Oncol 2010;28:4722-9. doi:10.1200/JCO.2010.28.6963. 
[15] Cancer Genome Atlas Research Network. Comprehensive genomic characterization defines human glioblastoma genes and core pathways. Nature 2008;455:1061-8. doi:10.1038/nature07385.

[16] Killela PJ, Reitman ZJ, Jiao Y, Bettegowda C, Agrawal N, Diaz LA, et al. TERT promoter mutations occur frequently in gliomas and a subset of tumors derived from cells with low rates of self-renewal. Proc Natl Acad Sci U S A 2013;110:6021-6. doi:10.1073/pnas.1303607110.

[17] Sturm D, Witt H, Hovestadt V, Khuong-Quang D-A, Jones DTW, Konermann C, et al. Hotspot mutations in $\mathrm{H} 3 \mathrm{~F} 3 \mathrm{~A}$ and IDH1 define distinct epigenetic and biological subgroups of glioblastoma. Cancer Cell 2012;22:425-37. doi:10.1016/j.ccr.2012.08.024.

[18] Parsons DW, Jones S, Zhang X, Lin JC-H, Leary RJ, Angenendt P, et al. An integrated genomic analysis of human glioblastoma multiforme. Science 2008;321:1807-12. doi:10.1126/science.1164382.

[19] Schwartzbaum JA, Fisher JL, Aldape KD, Wrensch M. Epidemiology and molecular pathology of glioma. Nat Clin Pract Neurol 2006;2:494-503; quiz 1 p following 516. doi:10.1038/ncpneuro0289.

[20] Cairncross G, Wang M, Shaw E, Jenkins R, Brachman D, Buckner J, et al. Phase III trial of chemoradiotherapy for anaplastic oligodendroglioma: long-term results of RTOG 9402. J Clin Oncol Off J Am Soc Clin Oncol 2013;31:337-43. doi:10.1200/JCO.2012.43.2674.

[21] Van den Bent MJ, Brandes AA, Taphoorn MJB, Kros JM, Kouwenhoven MCM, Delattre J-Y, et al. Adjuvant procarbazine, lomustine, and vincristine chemotherapy in newly diagnosed anaplastic oligodendroglioma: long-term follow-up of EORTC brain tumor group study 26951. J Clin Oncol Off J Am Soc Clin Oncol 2013;31:344-50. doi:10.1200/JCO.2012.43.2229. 
[22] Cairncross JG, Ueki K, Zlatescu MC, Lisle DK, Finkelstein DM, Hammond RR, et al. Specific genetic predictors of chemotherapeutic response and survival in patients with anaplastic oligodendrogliomas. J Natl Cancer Inst 1998;90:1473-9.

[23] Reifenberger J, Reifenberger G, Liu L, James CD, Wechsler W, Collins VP. Molecular genetic analysis of oligodendroglial tumors shows preferential allelic deletions on $19 \mathrm{q}$ and 1p. Am J Pathol 1994;145:1175-90.

[24] Yan H, Parsons DW, Jin G, McLendon R, Rasheed BA, Yuan W, et al. IDH1 and IDH2 mutations in gliomas. N Engl J Med 2009;360:765-73. doi:10.1056/NEJMoa0808710.

[25] Sanson M, Marie Y, Paris S, Idbaih A, Laffaire J, Ducray F, et al. Isocitrate dehydrogenase 1 codon 132 mutation is an important prognostic biomarker in gliomas. J Clin Oncol Off J Am Soc Clin Oncol 2009;27:4150-4. doi:10.1200/JCO.2009.21.9832.

[26] Idbaih A, Marie Y, Pierron G, Brennetot C, Hoang-Xuan K, Kujas M, et al. Two types of chromosome $1 \mathrm{p}$ losses with opposite significance in gliomas. Ann Neurol 2005;58:483-7. doi:10.1002/ana.20607.

[27] Jenkins RB, Blair H, Ballman KV, Giannini C, Arusell RM, Law M, et al. A $\mathrm{t}(1 ; 19)(\mathrm{q} 10 ; \mathrm{p} 10)$ mediates the combined deletions of $1 \mathrm{p}$ and $19 \mathrm{q}$ and predicts a better prognosis of patients with oligodendroglioma. Cancer Res 2006;66:9852-61. doi:10.1158/0008-5472.CAN-06-1796.

[28] Griffin CA, Burger P, Morsberger L, Yonescu R, Swierczynski S, Weingart JD, et al. Identification of $\operatorname{der}(1 ; 19)(\mathrm{q} 10 ; \mathrm{p} 10)$ in five oligodendrogliomas suggests mechanism of concurrent $1 \mathrm{p}$ and 19q loss. J Neuropathol Exp Neurol 2006;65:988-94. doi:10.1097/01.jnen.0000235122.98052.8f.

[29] Benetkiewicz M, Idbaih A, Cousin P-Y, Boisselier B, Marie Y, Crinière E, et al. NOTCH2 is neither rearranged nor mutated in $\mathrm{t}(1 ; 19)$ positive oligodendrogliomas. PloS One 2009;4:e4107. doi:10.1371/journal.pone.0004107. 
[30] Bettegowda C, Agrawal N, Jiao Y, Sausen M, Wood LD, Hruban RH, et al. Mutations in CIC and FUBP1 contribute to human oligodendroglioma. Science 2011;333:1453-5. doi:10.1126/science.1210557.

[31] Jiménez G, Shvartsman SY, Paroush Z. The Capicua repressor--a general sensor of RTK signaling in development and disease. J Cell Sci 2012;125:1383-91. doi:10.1242/jcs.092965.

[32] Zhang J, Chen QM. Far upstream element binding protein 1: a commander of transcription, translation and beyond. Oncogene 2013;32:2907-16. doi:10.1038/onc.2012.350.

[33] Cairncross JG, Wang M, Jenkins RB, Shaw EG, Giannini C, Brachman DG, et al. Benefit from procarbazine, lomustine, and vincristine in oligodendroglial tumors is associated with mutation of IDH. J Clin Oncol Off J Am Soc Clin Oncol 2014;32:78390. doi:10.1200/JCO.2013.49.3726.

[34] Capelle L, Fontaine D, Mandonnet E, Taillandier L, Golmard JL, Bauchet L, et al. Spontaneous and therapeutic prognostic factors in adult hemispheric World Health Organization Grade II gliomas: a series of 1097 cases: clinical article. J Neurosurg 2013;118:1157-68. doi:10.3171/2013.1.JNS121.

[35] Pignatti F, van den Bent M, Curran D, Debruyne C, Sylvester R, Therasse P, et al. Prognostic factors for survival in adult patients with cerebral low-grade glioma. J Clin Oncol Off J Am Soc Clin Oncol 2002;20:2076-84.

[36] Soffietti R, Baumert BG, Bello L, von Deimling A, Duffau H, Frénay M, et al. Guidelines on management of low-grade gliomas: report of an EFNS-EANO Task Force. Eur J Neurol Off J Eur Fed Neurol Soc 2010;17:1124-33. doi:10.1111/j.14681331.2010.03151.x. 
[37] Daniels TB, Brown PD, Felten SJ, Wu W, Buckner JC, Arusell RM, et al. Validation of EORTC prognostic factors for adults with low-grade glioma: a report using intergroup 86-72-51. Int J Radiat Oncol Biol Phys 2011;81:218-24. doi:10.1016/j.ijrobp.2010.05.003.

[38] Pallud J, Mandonnet E, Duffau H, Kujas M, Guillevin R, Galanaud D, et al. Prognostic value of initial magnetic resonance imaging growth rates for World Health Organization grade II gliomas. Ann Neurol 2006;60:380-3. doi:10.1002/ana.20946.

[39] Van den Bent MJ, Snijders TJ, Bromberg JEC. Current treatment of low grade gliomas. Memo 2012;5:223-7. doi:10.1007/s12254-012-0014-3.

[40] Viaccoz A, Lekoubou A, Ducray F. Chemotherapy in low-grade gliomas. Curr Opin Oncol 2012;24:694-701. doi:10.1097/CCO.0b013e328357f503.

[41] Johnson DR, Brown PD, Galanis E, Hammack JE. Pilocytic astrocytoma survival in adults: analysis of the Surveillance, Epidemiology, and End Results Program of the National Cancer Institute. J Neurooncol 2012;108:187-93. doi:10.1007/s11060-0120829-0.

[42] Wippold FJ, Perry A, Lennerz J. Neuropathology for the neuroradiologist: Rosenthal fibers. AJNR Am J Neuroradiol 2006;27:958-61.

[43] Jones DTW, Gronych J, Lichter P, Witt O, Pfister SM. MAPK pathway activation in pilocytic astrocytoma. Cell Mol Life Sci CMLS 2012;69:1799-811. doi:10.1007/s00018-011-0898-9.

[44] Roth JJ, Santi M, Pollock AN, Harding BN, Rorke-Adams LB, Tooke LS, et al. Chromosome Band 7q34 Deletions Resulting in KIAA1549-BRAF and FAM131BBRAF Fusions in Pediatric Low-Grade Gliomas. Brain Pathol Zurich Switz 2014. doi:10.1111/bpa.12167. 
[45] Chamberlain MC. Salvage therapy with BRAF inhibitors for recurrent pleomorphic xanthoastrocytoma: a retrospective case series. J Neurooncol 2013;114:237-40. doi:10.1007/s11060-013-1176-5.

[46] Skrypek M, Foreman N, Guillaume D, Moertel C. Pilomyxoid astrocytoma treated successfully with vemurafenib. Pediatr Blood Cancer 2014;61:2099-100. doi:10.1002/pbc.25084.

[47] Del Bufalo F, Carai A, Figà-Talamanca L, Pettorini B, Mallucci C, Giangaspero F, et al. Response of recurrent BRAFV600E mutated ganglioglioma to Vemurafenib as single agent. J Transl Med 2014;12:356. doi:10.1186/s12967-014-0356-1.

[48] Shete S, Hosking FJ, Robertson LB, Dobbins SE, Sanson M, Malmer B, et al. Genomewide association study identifies five susceptibility loci for glioma. Nat Genet 2009;41:899-904. doi:10.1038/ng.407.

[49] Wrensch M, Jenkins RB, Chang JS, Yeh R-F, Xiao Y, Decker PA, et al. Variants in the CDKN2B and RTEL1 regions are associated with high-grade glioma susceptibility. Nat Genet 2009;41:905-8. doi:10.1038/ng.408.

[50] Reuss DE, Sahm F, Schrimpf D, Wiestler B, Capper D, Koelsche C, et al. ATRX and IDH1-R132H immunohistochemistry with subsequent copy number analysis and IDH sequencing as a basis for an "integrated" diagnostic approach for adult astrocytoma, oligodendroglioma and glioblastoma. Acta Neuropathol (Berl) 2014. doi:10.1007/s00401-014-1370-3.

[51] Teo M, Clark B, MacKinnon M, Stewart W, Paul J, St George J. The validity of EORTC GBM prognostic calculator on survival of GBM patients in the West of Scotland. Br J Neurosurg 2014;28:356-62. doi:10.3109/02688697.2013.847171. 
[52] Wu G, Diaz AK, Paugh BS, Rankin SL, Ju B, Li Y, et al. The genomic landscape of diffuse intrinsic pontine glioma and pediatric non-brainstem high-grade glioma. Nat Genet 2014;46:444-50. doi:10.1038/ng.2938.

[53] Johnson BE, Mazor T, Hong C, Barnes M, Aihara K, McLean CY, et al. Mutational analysis reveals the origin and therapy-driven evolution of recurrent glioma. Science 2014;343:189-93. doi:10.1126/science.1239947.

[54] Heaphy CM, de Wilde RF, Jiao Y, Klein AP, Edil BH, Shi C, et al. Altered telomeres in tumors with ATRX and DAXX mutations. Science 2011;333:425. doi:10.1126/science.1207313.

[55] Chi AS, Batchelor TT, Kwak EL, Clark JW, Wang DL, Wilner KD, et al. Rapid radiographic and clinical improvement after treatment of a MET-amplified recurrent glioblastoma with a mesenchymal-epithelial transition inhibitor. J Clin Oncol Off J Am Soc Clin Oncol 2012;30:e30-3. doi:10.1200/JCO.2011.38.4586. 
Table. Main molecular biomarkers used or close to be used in clinical neuro-oncology

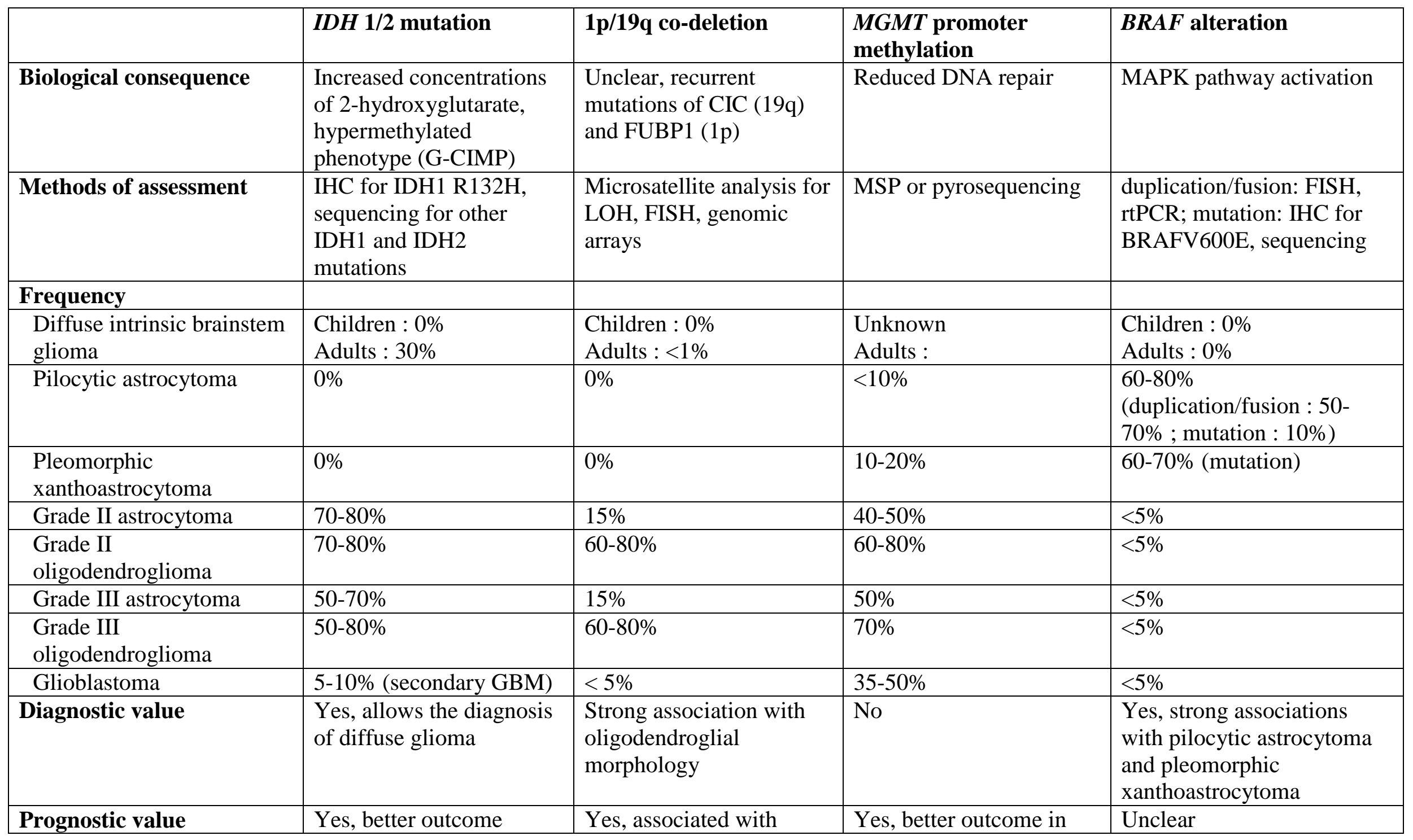




\begin{tabular}{|c|c|c|c|c|}
\hline & across histologies & $\begin{array}{l}\text { better outcome in grade II } \\
\text { and III gliomas }\end{array}$ & grade II to IV gliomas & \\
\hline
\end{tabular}

IDH: isocitrate dehydrogenase; IHC: immunohistochemistry; GBM: glioblastoma; LOH: loss of heterozygosity; FISH: fluorescence in situ hybridization; MSP:methylation specific PCR; rtPCR: real-time PCR 
Figure 2

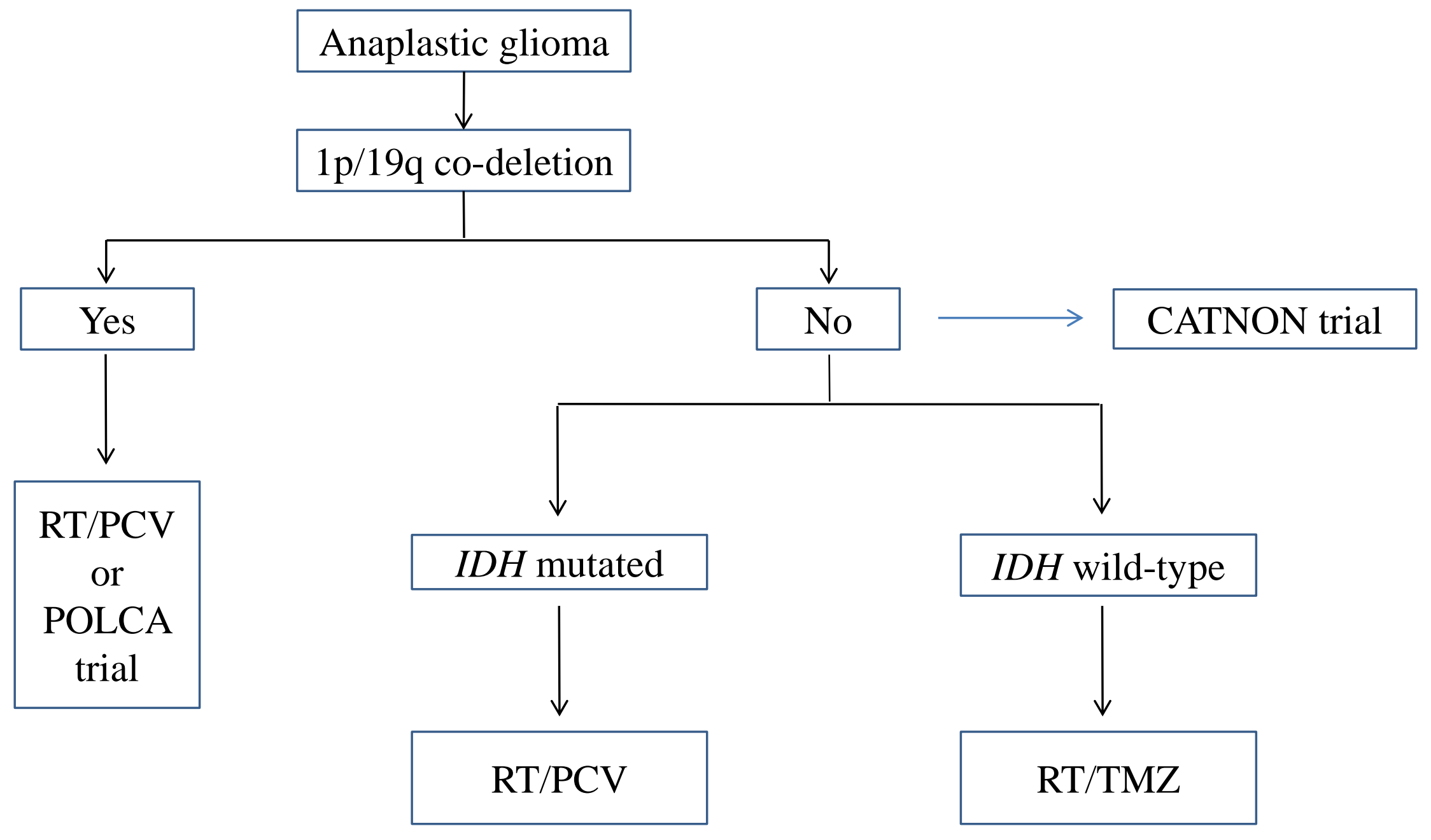

